\title{
Keanekaragaman dan Dominansi Gulma pada Ekosistem Padi di Lahan Pasang Surut Kabupaten Indragiri Hilir
}

\section{Diversity and Dominance of Weeds on Tidal Swamp Rice Ecosystems in Indragiri Hilir District}

\author{
Zahlul Ikhsan $^{1,2, *}$, Hidrayani ${ }^{1}$, Yaherwandi ${ }^{1}$ dan Hasmiandy Hamid ${ }^{1}$ \\ ${ }^{1}$ Fakultas Pertanian, Universitas Andalas \\ ${ }^{2}$ Fakultas Pertanian, Universitas Islam Indragiri \\ *Email korespondensi: zahlul_ikh@yahoo.com
}

Diterima: 14 Agustus 2020 / Disetujui: 16 September 2020

\begin{abstract}
Rice (Oryza sativa L.) is one of the primary food crop commodities in Indonesia. The need for rice is always increasing every year, so efforts are needed to increase rice production. One of the things that can inhibit the rice production was weeds. The first step to control weed was identifying the type of weeds. This study aims was to identify the dominance of weeds found in tidal paddy fields in Indragiri Hilir Regency. The study was conducted on tidal land owned by farmers in Indragiri Hilir Regency, Riau Province. The study was conducted at four locations, namely in the districts of Batang Tuaka, Keritang, Reteh, and Tembilahan Hulu. The research was carried out using a survey and exploration methods. The results revealed that 12 families consisted of 20 species of weeds in the tidal land rice plantations of Indragiri downstream. Based on the Taxonomy, there are seven species of monocot weeds and 13 dicotyledons. Based on the morphology, there are 12 species of broadleaf weeds, five species of grasses weeds, two species of fern weeds, and one species of Cyperaceae weeds. Ageratum conyzoides and Imperata cylindrica species are the most dominant weeds in rice plantations with an SDR (Summed Dominance Ratio) of 9.57\% each.
\end{abstract}

Keywords: food, Oryza sativa, tidal land, SDR

\section{ABSTRAK}

Padi (Oryza sativa L.) adalah salah satu komoditi tanaman pangan utama di Indonesia. Kebutuhan akan padi selalu meningkat setiap tahunnya, sehingga dibutuhkan upaya untuk meningkatkan produksi padi. Salah satu hal yang menghambat peningkatan produksi padi adalah keberadaan gulma. Hal yang pertama dilakukan dalam pengendalian gulma adalah melalui proses Penelitian ini bertujuan untuk mengidentifikasi dominansi gulma yang terdapat pada pertanaman padi sawah pasang surut di Kabupaten Indragiri Hilir. Penelitian dilakukan pada lahan padi pasang surut milik petani di Kabupaten Indragiri Hilir, Provinsi Riau. Penelitian dilakukan pada empat lokasi, yaitu di Kecamatan Batang tuaka, Keritang, Reteh dan Tembilahan hulu. Pelaksanaan penelitian dilakukan dengan metode survey dan eksplorasi. Hasil penelitian mengungkapkan bahwa terdapat 12 famili yang terdiri dari 20 spesies gulma di pertanaman padi lahan pasang surut Kabupaten Indragiri hilir. Berdasarkan Taksonomi terdapat 7 spesies gulma monokotil dan 13 dikotil. Berdasarkan morfologi terdapat 12 spesies gulma berdaun lebar, 5 spesies gulma rerumputan, 2 spesies gulma pakis-pakisan dan 1 spesies gulma tekian. Spesies Ageratum conyzoides dan Imperata cylindrica merupakan gulma yang paling mendominasi pada pertanaman padi dengan NJD masing-masing sebesar $9,57 \%$.

Kata kunci: lahan pasang surut, NJD, Oryza sativa, pangan

\section{PENDAHULUAN}

Padi (Oryza sativa L.) adalah salah satu komoditi tanaman pangan utama di Indonesia. Dengan demikian, kebutuhan padi selalu meningkat seiring pertambahan jumlah penduduk. Oleh sebab itu perlu diusahakan peningkatan produktivitas tanaman padi secara terus menerus, salah satu caranya yaitu dengan ekstensifikasi padi di lahan rawa pasang surut.

Kabupaten Indragiri Hilir merupakan daerah rawa pasang surut dengan penyebaran sungai hampir di seluruh kecamatan. Ekosistem lahan rawa memiliki sifat khusus yang lahan yang kondisi airnya bersumber dan dipengaruhi oleh pasang surut air laut atau sungai (Haryono et al., 2013). Lahan rawa pasang surut mempunyai berbagai jenis flora dari jenis rumput-rumputan, semak dan pohon (Thamrin, 2011). Hal inilah yg memungkinkan banyaknya jenis gulma yang berada disekitar pertanaman padi di lahan pasang surut.

Gulma merupakan tumbuhan yang tumbuh pada tempat yang tidak dikehendaki. Keberadaan gulma dapat mengakibatkan kerugian secara langsung dan tidak langsung bagi tanaman. Kerugian secara langsung adalah dalam hal memperebutkan unsur hara, air maupun cahaya, sedangkan secara tidak langsung dapat menjadi inang bagi hama dan

DOI: https://doi.org/10.21107/agrovigor.v13i2.7463

Agrovigor: Jurnal Agroekoteknologi http://journal.trunojoyo.ac.id/agrovigor ISSN: 1979-5777 (Print), 2477-0353 (Online) 
gulma di lahan pertanian dapat menurunkan produksi dan produktivitas tanaman.

Gulma adalah salah satu Organisme Pengganggu Tanaman (OPT) atau jasad pengganggu tanaman. Gulma merupakan tumbuhan yang mengganggu pertumbuhan tanaman atau merugikan kepentingan manusia sehingga manusia berusaha untuk mengendalikannya (Sembodo, 2010; Kilkoda, 2015). Nantasomsaran dan Moody (1993) melaporkan bahwa keberadaan gulma di pertanaman padi sawah dapat menurunkkan produksi padi hingga 10-40\%. Persentase penurunan tersebut sangat tergantung pada spesies dan kepadatan gulma, jenis tanah, pasokan air, dan keadaan iklim. Selain itu, gulma dapat mengeluarkan zat allelopati Yang dapat mengganggu pertumbuhan tanaman hingga menyebabkan kematian tanaman budidaya. Dengan demikian, diperlukan adanya pengendalian gulma di lahan pertanian.

Salah satu cara awal pengendalian gulma adalah dengan cara identifikasi keragaman dan dominansi gulma. Hasil penelitian Dahlianah (2017) menyatakan bahwa terdapat terdapat 4 famili, 5 genus, dan 7 spesies gulma di lahan padi pasang surut Desa Manggaraya Kecamatan Tanjung Lago Kabupaten Banyuasin, Provinsi Sumatera Selatan. Struktur gulma padi di lahan pasang surut dengan nilai INP tertinggi adalah jenis gulma Echinochloa crussgalli (41,16\%). Hasil penelitian Agustina \& Yursida (2015) menunjukkan gulma dominan pada pertanaman padi di Lahan Pasang Surut Desa Banyu Urip Kecamatan Tanjung Lago dengan memiliki rata-rata Nisbah Jumlah Dominansi tertinggi berturut-turut adalah: Ludwigia octovalvis, Fymbristilis littoralis, Alternanthera philoxeroides dan Cyperus kylingia.

Pengendalian gulma efektif dilakukan apabila telah mengetahui jenis-jenis gulma pada lahan sawah. Menurut Kastanja (2011) keberhasilan pengendalian gulma harus didasari dengan pengetahuan yang cukup dan benar dari sifat biologi gulma melalui identifikasi, cara tersebut merupakan langkah pertama untuk menjajaki kemungkinan pengendalian yang tepat (Sukma dan Yakup, 2002). Penelitian ini bertujuan untuk mengidentifikasi dan melihat dominansi gulma yang terdapat pada pertanaman padi sawah pasang surut di Kabupaten Indragiri Hilir.

\section{BAHAN DAN METODE}

\section{Tempat dan Waktu Penelitian}

Penelitian dilaksanakan pada bulan Januari November 2019 di Sentra produksi padi lahan pasang surut Kabupaten Indragiri Hilir, yaitu Kecamatan Batang tuaka, Keritang, Reteh dan Tembilahan hulu. Bahan yang digunakan dalam penelitian ini adalah gulma. Alat yang digunakan adalah cangkul, gunting, kantong, kertas, kertas label, meteran, mistar, parang, sekop, tali rafia, kamera dan alat tulis.

Pelaksanaan penelitian dilakukan dengan metode survey dan eksplorasi. Pada masing-masing kecamatan ditentukan satu lahan padi yang dijadikan sebagai lokasi sampel penelitian, sehingga didapat empat lokasi lahan petani. Lokasi penelitian adalah lahan sawah petani yang tidak sedang dalam proses pembasmian gulma. Pengambilan spesimen gulma dilakukan dengan metode eksplorasi. Spesimen yang diambil merupakan perwakilan dari satu spesies gulma yang ada pada tanaman padi.

\section{Pengambilan sampel gulma}

Pengambilan sampel gulma dilakukan melalui metode jelajah (eksplorasi) (Suryaningsih et al., 2011). Metode ini dilakukan dengan menjelajah di empat lokasi sampel, Sekaligus mengambil sampel yang mewakili masing-masing spesies.

\section{Identifikasi gulma}

Identifikasi gulma dilakukan untuk mendapatkan informasi lebih lanjut mengenai gulma yang didapat pada lokasi penelitian. Identifikasi dilakukan di Laboratorium Agronomi Fakultas Pertanian Universitas Andalas.

\section{Pengelompokan gulma}

Pengelompokan gulma dilakukan menggunakan metode skoring yang pertama kali diperkenalkan oleh Hiebert dan Stubbendieck (1993), dan dikembangkan oleh Tjitrosoedirdjo (2010). Nilai yang diperoleh dari setiap karakteristik kemudian dianalisis. Beberapa peubah pengamatan yang diamati dalam penelitian ini antara lain 1) Deskripsi spesies dan family (Spesimen gulma yang telah diambil dimati karakter morfologinya dan dibuat menjadi herbarium). 2) Pengelompokkan gulma berdasarkan morfologi, 3) Titik penyebaran (gulma yang ditemukan pada lahan penelitian diplot dalam peta lahan penelitian sesuai keadaan di lapangan). 4) Titik sebaran, (bisa terdiri dari satu jenis gulma atau lebih). 5) Cara perbanyakan (dengan cara memperhatikan organ reproduksi masing-masing spesimen gulma dan dari literatur).

\section{Analisis Data}

Pengelompokan gulma dilaksanakan menggunakan metode skoring berdasarkan kriterianya yang pertama kali diperkenalkan oleh Hiebert dan Stubbendieck (1993) dan dikembangkan oleh Tjitrosoedirdjo (2010). Nilai yang diperoleh dari setiap karakteristik kemudian diuji multivariate cluster untuk melihat pengelompokan dari gulma-gulma tersebut. Pengelompokkan disajikan dalam bentuk dendogram yang dianalisis menggunakan program Minitab 16.

\section{Nisbah Jumlah Dominansi}

Nisbah jumlah dominansi gulma (NJD atau Nilai Jumlah Dominansi) dihitung menurut Moenandir (1993) dengan Persamaan :

$$
\text { NJD }=\frac{\text { Frekuensi }+ \text { Jumlah }+ \text { Berat kering }}{3}
$$

Namun karena berat gulma relative sulit diperoleh, maka NJD (\%), dimodifikasi menjadi:

$$
\mathrm{NJD}=\frac{\text { Frekuensi relatif }+ \text { Kerapatan relatif }}{2}
$$


Frekuensi Relatif (FR) dihitung dengan rumus:

$$
\mathrm{FR}=\frac{\text { Frekuensi mutlak spesies tertentu }}{\text { Total frekuensi mutlak semua spesies }}
$$

Frekuensi Mutlak yaitu keberadaan jenis gulma tertentu relative terhadap total lokasi. Misalnya, gulma A ditemukan pada 20 lokasi, maka Frekuensi Mutlaknya adalah :

$$
\mathrm{FM}=\frac{20 \times 100 \%}{192}=10,41
$$

Kerapatan Relatif (KR) dihitung dengan rumus (Titik penyebaran dianggap sebagai potensi penyebaran gulma di lahan:

$$
\mathrm{KR}=\frac{\text { Titik penyebaran spesies tertentu }}{\text { Total titik penyebaran semua spesies }}
$$

\section{HASIL DAN PEMBAHASAN}

\section{Spesies Gulma di Lahan Sawah Pasang Surut}

Penelitian dilakukan di sentra produksi padi Kabupaten Indragiri Hilir, yaitu di kecamatan Batang Tuaka, Keritang, Reteh dan Tembilahan Hulu. Pada masing-masing kecamatan terdapat satu lahan padi pasang surut yang dijadikan sebagai lokasi sampel penelitian. Hasil pengamatan jenis gulma yang ditemukan disajikan pada Tabel 1.

Hasil penelitian menunjukkan bahwa famili poacea memiliki spesies terbanyak di lahan padi pasang surut (5 spesies), yaitu Centotheca latifolia, Eleusine indica, Imperata cylindrica, Polytrias amaura, dan Sporobolus diander. Selanjutnya famili Euphorbiaceae (4 spesies), yaitu Euphorbia hirta, Phyllanthus maderaspatensi, Phyllanthus niruri, dan Phyllanthus urinaria. Sedangkan spesies dari famili Asteraceae, Amaranthaceae, Acanthaceae, Ciperaceae, Capparales, Dryopteridaceae, Acanthaceae, Ciperaceae, Capparales dan Dryopteridaceae tidak banyak ditemukan. Gulma dari Famili Poaceae ditemukan pada seluruh lokasi penelitian. Famili Poaceae memiliki jumlah spesies tertinggi karena semua anggota famili ini merupakan tumbuhan sederhana, memiliki alat perkembangbiakan yang ringan sehingga mudah dipencar serta mudah hidup pada berbagai tipe habitat. Gulma dari famili Poaceae adalah gulma yang adaptif. Hal ini sesuai dengan pernyataan Faisal et al., (2011), jenis gulma ini toleran terhadap cekaman kekeringan, suhu tinggi, dan mampu bertahan toleran terhadap panas, mampu hidup di tanah miskin unsur hara. Selain itu juga mengeluarkan zat alelokima berupa senyawa fenol yang bersifat racun terhadap tumbuhan lainya. Famili Poaceae adalah gulma berdaun sempit, memiliki akar rimpang. Akar ini membentuk jaringan rumit didalam tanah dan sulit diatasi secara mekanik (Harsono, 2011). Species gulma dari Famili Poaceae dapat berkembang biak secara generatif dan vegetatif (dengan rimpang, umbi dan tunas). Akibatnya gulma tersebut dapat beradaptasi dan menguasai areal tanaman bersaing dengan tanaman pokok. Hal ini sesuai dengan pendapat Suryaningsih et al., (2001), bahwa Familia Poaceae termasuk golongan gulma yang mempunyai kemampuan perbanyakan yang tinggi.

Gulma famili Euphorbiaceae ditemukan di seluruh lokasi penelitian, hal ini menujukkan bahwa gulma dari famili ini merupakan gulma yang mampu hidup di berbagai lingkungan. Zulkarnain (2011) menambahkan bahwa gulma dari Famili Euphorbiaceae mampu bertahan hidup selama 1

\begin{tabular}{|c|c|c|c|c|c|c|}
\hline \multirow{2}{*}{ No } & \multirow{2}{*}{ Famili } & \multirow{2}{*}{ Nama Spesies } & \multicolumn{4}{|c|}{ Lokasi } \\
\hline & & & 1 & 2 & 3 & 4 \\
\hline 1 & Asteraceae & Ageratum conyzoides & $\mathrm{x}$ & $\mathrm{x}$ & $\mathrm{x}$ & \\
\hline \multirow[t]{2}{*}{2} & Amaranthaceae & Alternanthera philoxeroides & $\mathrm{x}$ & & & \\
\hline & & Amaranthus spinosus & & $\mathrm{x}$ & & \\
\hline 3 & Acanthaceae & Asystasia gangetica & & $\mathrm{x}$ & $\mathrm{x}$ & $\mathrm{x}$ \\
\hline 4 & Ciperaceae & Cyperus rotundus & & $\mathrm{x}$ & $\mathrm{x}$ & $\mathrm{x}$ \\
\hline 5 & Capparales & Cleome aspera & $\mathrm{x}$ & & & \\
\hline 6 & Dryopteridaceae & Dryopteris cucullata & & $\mathrm{x}$ & & \\
\hline \multirow[t]{4}{*}{7} & Euphorbiaceae & Euphorbia hirta & $\mathrm{x}$ & $\mathrm{x}$ & $\mathrm{x}$ & \\
\hline & & Phyllanthus maderaspatensis & & $\mathrm{x}$ & & \\
\hline & & Phyllanthus niruri & & & & $\mathrm{x}$ \\
\hline & & Phyllanthus urinaria & & & & $\mathrm{x}$ \\
\hline 8 & Acanthaceae & Crotalaria verrucosa & & & & $\mathrm{x}$ \\
\hline 9 & Ciperaceae & Limnocharis flava & $\mathrm{x}$ & & $\mathrm{x}$ & $\mathrm{x}$ \\
\hline 10 & Capparales & Melastoma malabathricum & $\mathrm{x}$ & & $\mathrm{x}$ & $\mathrm{x}$ \\
\hline 11 & Dryopteridaceae & Ceratopteris thalictroides & & & & $\mathrm{x}$ \\
\hline \multirow[t]{5}{*}{12} & Poaceae & Centotheca latifolia & & & & $\mathrm{x}$ \\
\hline & & Eleusine indica & $\mathrm{x}$ & & $\mathrm{x}$ & \\
\hline & & Imperata cylindrical & & $\mathrm{x}$ & $\mathrm{x}$ & \\
\hline & & Polytrias amaura & & $\mathrm{x}$ & & \\
\hline & & Sporobolus diander & & $\mathrm{x}$ & & $\mathrm{x}$ \\
\hline
\end{tabular}
tahun dan berkembang biak dengan biji.

Tabel 1. Famili dan Spesies Gulma pada Pertanaman Padi di Lahan Pasang Surut Kabupaten Indragiri Hilir.

Tabel 1 juga menunjukkan bahwa dominansi spesies gulma pada setiap lokasi lahan persawahan padi pasang surut berbeda-beda. Menurut Sari dan Rahayu (2013), yang memengaruhi keanekaragaman jenis gulma adalah faktor 
internal dan eksternal. Faktor internal yang berpengaruh yaitu adanya kemampuan bereproduksi, adaptasi dan kompetisi, sedangkan faktor eksternal yang berpengaruh adalah iklim, jenis tanah, cara pengendalian, cara bercocok tanam dan jenis tanaman budidaya. Selanjutnya Sastroutomo (1990) menyatakan bahwa beberapa hal yang berpengaruh terhadap pertumbuhan dan penyebaran gulma adalah faktor lingkungan seperti jenis dan tingkat kesuburan tanah, ketinggian tempat, serta keadaan air tanah dan praktek budidaya seperti pengolahan tanah dan pengendalian gulma.

\section{Pengelompokan Gulma Berdasarkan Klasifikasi Taksonomi}

Gulma dikotil merupakan gulma yang paling banyak ditemukan pada lahan percobaan sawah pasang surut, yaitu 13 spesies atau $65 \%$ dari total gulma yang didapatkan (Gambar 1). Spesies gulma dikotil yang ditemukan adalah Ageratum conyzoides, Alternanthera philoxeroides, Amaranthus spinosus, Asystasia gangetica, Ceratopteris thalictroides, Cleome aspera, Crotalaria verrucosa, Euphorbia hirta, Melastoma malabathricum, Phyllanthus maderaspatensis, Phyllanthus niruri, Phyllanthus urinaria, dan Polytrias amaura. Spesies gulma monokotil yang ditemukan ada 7 spesies, yaitu Centotheca latifolia, Cyperus rotundus, Dryopteris cucullata, Eleusine indica, Imperata cylindrical, Limnocharis flava, dan Sporobolus diander.

Jenis gulma yang tumbuh di area persawahan pasang surut lebih banyak yang tergolong dikotil jika dibandingkan dengan monokotil. Hal ini dapat terjadi karena lahan sawah tersebut merupakan sawah yang kondisi tanahnya lebih sering lembab atau tergenang. Menurut Pane dan Jatmiko (2009), gulma dikotil tumbuh dominan pada kondisi air tergenang, sedangkan gulma monokotil tumbuh dominan pada kondisi kering. Menurut Ikbal et al., (2016) pada lahan sawah irigasi umumnya gulma didominasi oleh gulma dikotil, karena itu kehilangan hasil lebih kecil dari hasil padi di sawah tadah hujan atau padi gogo yang umumnya didominasi oleh gulma monokotil.

Perbedaan takson masing-masing tumbuhan dengan fisiologi yang berbeda mempunyai kemampuan adaptasi yang berbeda, dimana spesies dengan sebaran spektrum luas mempunyai kemampuan adaptasi yang lebih tinggi jika dibandingkan dengan spesies yang memiliki sebaran spektrum sempit. Hyene (1987) mengungkapkan bahwa tumbuhan yang hidup pada kondisi lingkungan yang tidak spesifik mempunyai kemampuan beradaptasi yang baik, sehingga tumbuhan tersebut dapat ditemukan di dataran rendah dan dataran tinggi. Berdasarkan gambar 1, dapat dilihat bahwa gulma dikotil lebih mendominasi pada pertanaman padi di lahan pasang surut. Hal ini dapat disebabkan karena gulma dikotil dapat lebih beradaptasi pada sawah yang kondisi tanahnya lebih sering lembab atau tergenang.

Pengelompokan Gulma Berdasarkan Morfologi
Berdasarkan morfologi, gulma dapat dikelompokkan menjadi gulma berdaun lebar, gulma teki-tekian, dan gulma rumputan. spesies gulma yang ada pada lahan sawah pasang surut didominasi oleh gulma berdaun lebar yang terdiri dari 12 spesies dan diikuti oleh gulma rerumputan yang terdiri dari 5 spesies. Sementara gulma pakis terdapat 2 spesies dan gulma teki 1 spesies saja (Tabel 2).

Gulma berdaun lebar mememiliki dominansi paling besar ( $60 \%$ ). Gulma berdaun lebar merupakan jenis gulma dari ordo Dicotyleneae akan tetapi ada juga beberapa yang berasal dari ordo monocotyledonae. Gulma ini tumbuh dengan habitus yang besar, sehingga terjadi kompetisi dengan tanaman, terutama dalam hal mendapatkan cahaya (Harsono, 2011). Kemampuan adaptasi gulma berdaun lebar untuk tumbuh pada lahan yang dibudidayakan sangat besar, sesuai dengan pendapat Purnomo (2011) gulma ini mampu beradaptasi dengan kondisi lingkungan yang kurang menguntungkan, sehingga angka kematiannya rendah, dan diikuti munculnya individu-individu baru selama perkembangannya. Namun ada beberapa jenis gulma yang individu - individunya akan mengalami kematian setelah melewati masa reproduksinya.

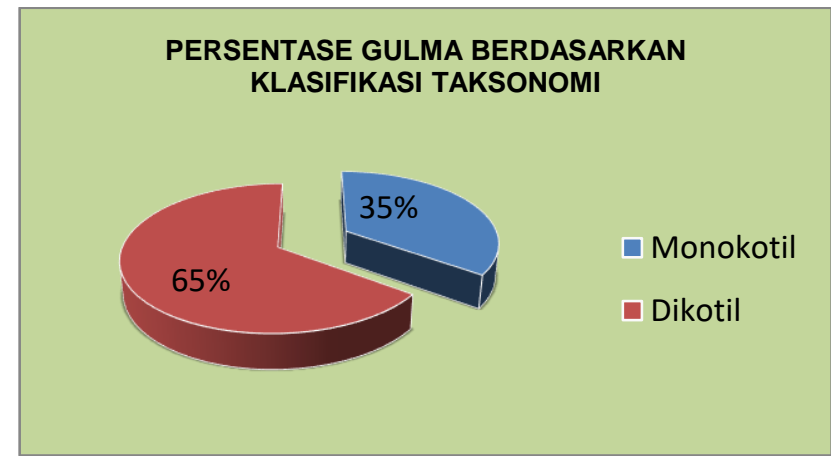

Gambar 1. Persentase Gulma Berdasarkan Klasifikasi Taksonomi Pada Pertanaman Padi di Lahan Pasang Surut Kabupaten Indragiri Hilir

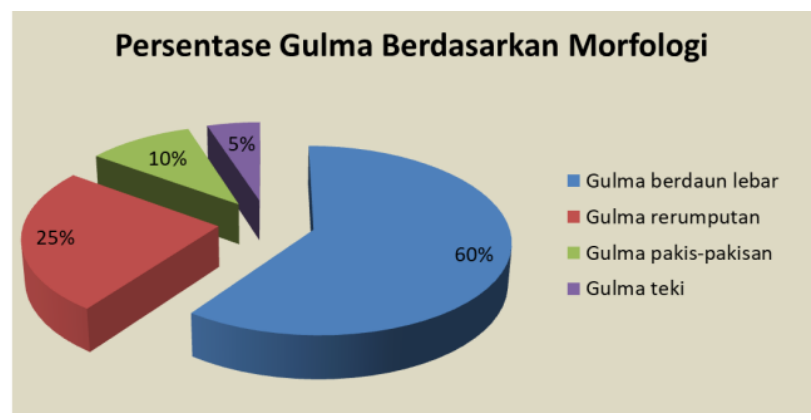

Gambar 2. Persentase Gulma Pada Pertanaman Padi di Lahan Pasang Surut Kabupaten Indragiri Hilir Berdasarkan Morfologi. 
Tabel 2. Pengelompokan Gulma Pada Pertanaman Padi di Lahan Pasang Surut Kabupaten Indragiri Hilir Berdasarkan Morfologi

\begin{tabular}{lll}
\hline No $\quad$ Kelompok Gulma & Spesies \\
\hline 1 & Gulma berdaun lebar & Ageratum conyzoides \\
& Alternanthera philoxeroides \\
& Amaranthus spinosus \\
& Asystasia gangetica \\
& Cleome aspera \\
& Crotalaria verrucosa \\
& Euphorbia hirta \\
& Limnocharis flava \\
& Melastoma malabathricum \\
& Phyllanthus maderaspatensis \\
& Phyllanthus niruri \\
& Phyllanthus urinaria \\
& Centotheca latifolia \\
& Eleusine indica \\
& Gulma rerumputan & Imperata cylindrica \\
& Polytrias amaura \\
& Gporobolus diander \\
& Gulma pakis-pakisan & Ceratopteris thalictroides \\
& Gryopteris cucullata \\
\hline
\end{tabular}

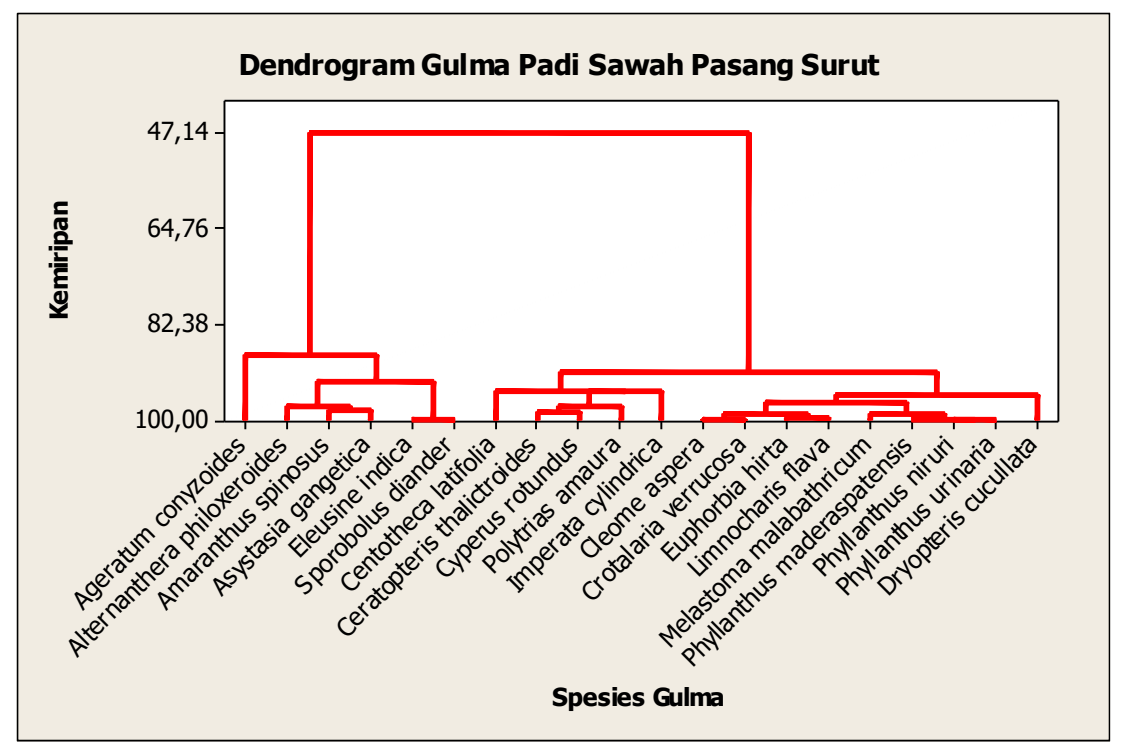

Gambar 3. Dendogram Pengelompokan Tingkatan Gulma di Lahan Sawah Pasang Surut.

\section{Pengelompokan Gulma}

Berdasarkan uji statistik, dalam penelitian ini gulma dikelompokkan menjadi 2 kelompok besar (Gambar 3). Kelompok pertama terdiri dari Ageratum conyzoides, Alternanthera philoxeroides, Amaranthus spinosus, Asystasia gangetica, Eleusine indica dan Sporobolus diander. Kelompok pertama memiliki nilai kemiripan dengan rentang nilai 87,96 - 100. Kelompok dua terdiri dari Centotheca latifolia, Ceratopteris thalictroides, Cyperus rotundus, Polytrias amaura, Imperata cylindrica, Cleome aspera, Crotalaria verrucosa, Euphorbia hirta, Limnocharis flava,
Melastoma malabathricum, Phyllanthus maderaspatensis, Phyllanthus niruri, Phyllanthus urinaria dan Dryopteris cucullata. Kelompok kedua merupakan kelompok gulma dengan total nilai tinggi dengan nilai kemiripan berkisar 94,69 - 100. Nilai kemiripan yang tinggi tersebut mengandung makna bahwa kelompok gulma ini mempunyai dampak yang signifikan terhadap kestabilan habitat pada lahan sawah padi pasang surut milik petani di Kabupaten Indragiri Hilir. Hal ini diakibatkan karena keberadaan gulma kelompok 2 ini lebih dominan di lahan padi pasang surut, sehingga memiliki dampak yang signifikan terhadap pertumbuhan dan produksi padi. Kondisi ini menunjukkan 
bahwa perlu adanya metode yang tepat untuk pengendalian kelompok gulma kelompok 2.

\section{Summed Dominance Ratio (SDR) Gulma}

Nilai SDR diartikan sebagai Nilai Jumlah Dominansi (NJD) menunjukkan hubungan dominansi satu spesies dengan spesies lain. Perhitungan NJD dilakukan berdasarkan pengamatan visual pada seluruh petak sampel tanpa menggunakan petak contoh. Nilai penting diperoleh dengan menjumlahkan Kerapatan Relatif dengan Frekuensi Relatif. Kerapatan Relatif dihitung dari banyaknya titik penyebaran spesies gulma tertentu dibagi total titik penyebaran semua spesies. Titik penyebaran digunakan untuk menggantikan kerapatan nisbi pada perhitungan NJD yang baku. Hal tersebut dikarenakan pada beberapa titik penyebaran terdapat lebih dari satu jenis gulma yang berasosisasi. Titik penyebaran dianggap sebagai potensi sumber penyebaran gulma.

Tabel 3 menunjukkan bahwa spesies Ageratum conyzoides dan Imperata cylindrica merupakan gulma yang paling mendominasi di lahan persawahan padi milik petani dengan SDR masing-masing sebesar 9.57\%. Gulma dominan selanjutnya adalah Euphorbia hirta dengan SDR sebesar $8.54 \%$. Spesies yang paling banyak ditemukan adalah
Ageratum conyzoides dan Imperata cylindrica (Tabel 3). Hal ini dapat disebabkan karena gulma tersebut mampu beradaptasi dengan berbagai jenis lingkungan. Selain itu, juga didukung oleh adanya potensi mengeluarkan senyawa alelopati. Imperata cylindrica juga memiliki alelopati dapat meningkatkan agresivitas gulma dalam hubungan interaksi antara gulma dan tanaman budidaya. Selain itu, biji Imperata cylindrica juga memiliki daya sebar tinggi. Sukman dan Yakup (2002) menambahkan bahwa rhizoma dari alangalang merupakan batang menjalar di bawah tanah dan hidupnya dapat bertahun-tahun. Batang yang menjalar di bawah tanah ini dapat tumbuh menjadi batang baru, karena mempunyai mata tunas pada buku batangnya.

\section{KESIMPULAN}

Gulma yang ada pada pertanaman padi di lahan pasang surut Kabupaten Indragiri Hilir ada 12 famili yang terdiri dari 20 spesies. Berdasarkan Taksonomi terdapat 7 spesies gulma monokotil dan 13 dikotil. Berdasarkan morfologi terdapat 12 spesies gulma berdaun lebar, 5 spesies gulma rerumputan, 2 spesies gulma pakis-pakisan dan 1 spesies gulma tekian. Ageratum conyzoides dan Imperata cylindrica merupakan gulma yang paling mendominasi dengan SDR masingmasing sebesar $9.57 \%$.

Tabel 3. Nilai Jumlah Dominansi (NJD) Gulma Pada Pertanaman Padi di Lahan Pasang Surut Kabupaten Indragiri Hilir

\begin{tabular}{|c|c|c|c|c|c|c|c|c|c|c|c|}
\hline \multirow{2}{*}{ No } & \multirow{2}{*}{ Jenis Gulma } & \multicolumn{4}{|c|}{ Kecamatan } & \multirow{2}{*}{$\mathrm{KM}$} & \multirow{2}{*}{ FM } & \multirow{2}{*}{$\mathrm{KN}$} & \multirow{2}{*}{$\mathrm{FN}$} & \multirow{2}{*}{ INP } & \multirow{2}{*}{ NJD } \\
\hline & & BT & $\mathrm{K}$ & $\mathrm{R}$ & TH & & & & & & \\
\hline 1 & Ageratum conyzoides & 22 & 15 & 12 & 10 & 59 & 4 & $\begin{array}{c}12,1 \\
1\end{array}$ & 7,02 & 19,13 & 9,57 \\
\hline 2 & $\begin{array}{l}\text { Alternanthera } \\
\text { philoxeroides }\end{array}$ & 7 & 0 & 2 & 0 & 9 & 2 & 1,85 & 3,51 & 5,36 & 2,68 \\
\hline 3 & Amaranthus spinosus & 2 & 9 & 8 & 0 & 19 & 3 & 3,90 & 5,26 & 9,16 & 4,58 \\
\hline 4 & Asystasia gangetica & 0 & 15 & 10 & 9 & 34 & 3 & 6,98 & 5,26 & 12,24 & 6,12 \\
\hline 5 & Centotheca latifolia & 2 & 0 & 0 & 7 & 9 & 2 & 1,85 & 3,51 & 5,36 & 2,68 \\
\hline 6 & Ceratopteris thalictroides & 0 & 6 & 0 & 7 & 13 & 2 & 2,67 & 3,51 & 6,18 & 3,09 \\
\hline 7 & Cleome aspera & 6 & 0 & 0 & 1 & 7 & 1 & 1,44 & 1,75 & 3,19 & 1,60 \\
\hline 8 & Crotalaria verrucosa & 0 & 2 & 0 & 6 & 8 & 2 & 1,64 & 3,51 & 5,15 & 2,58 \\
\hline 9 & Cyperus rotundus & 9 & 9 & 13 & 16 & 47 & 4 & 9,65 & 7,02 & 16,67 & 8,33 \\
\hline 10 & Dryopteris cucullata & 0 & 7 & 0 & 0 & 7 & 1 & 1,44 & 1,75 & 3,19 & 1,60 \\
\hline 11 & Eleusine indica & 13 & 7 & 10 & 10 & 40 & 4 & 8,21 & 7,02 & 15,23 & 7,62 \\
\hline 12 & Euphorbia hirta & 8 & 16 & 12 & 13 & 49 & 4 & $\begin{array}{c}10,0 \\
6\end{array}$ & 7,02 & 17,08 & 8,54 \\
\hline 13 & Imperata cylindrica & 12 & 17 & 16 & 14 & 59 & 4 & $\begin{array}{c}12,1 \\
1\end{array}$ & 7,02 & 19,13 & 9,57 \\
\hline 14 & Limnocharis flava & 7 & 10 & 13 & 15 & 45 & 4 & 9,24 & 7,02 & 16,26 & 8,13 \\
\hline 15 & Melastoma malabathricum & 13 & 12 & 9 & 8 & 42 & 4 & 8,62 & 7,02 & 15,64 & 7,82 \\
\hline 16 & $\begin{array}{l}\text { Phyllanthus } \\
\text { maderaspatensis }\end{array}$ & 3 & 7 & 2 & 0 & 12 & 3 & 2,46 & 5,26 & 7,73 & 3,86 \\
\hline 17 & Phyllanthus niruri & 3 & 0 & 0 & 7 & 10 & 2 & 2,05 & 3,51 & 5,56 & 2,78 \\
\hline 18 & Phyllanthus urinaria & 5 & 7 & 0 & 6 & 18 & 3 & 3,70 & 5,26 & 8,96 & 4,48 \\
\hline 19 & Polytrias amaura & 0 & 6 & 5 & 0 & 11 & 2 & 2,26 & 3,51 & 5,77 & 2,88 \\
\hline 20 & Sporobolus diander & 0 & 4 & 6 & 8 & 18 & 3 & 3,70 & 5,26 & 8,96 & 4,48 \\
\hline & Total & 112 & 149 & $\begin{array}{c}11 \\
8\end{array}$ & 137 & 487 & 57 & $\begin{array}{c}100, \\
0\end{array}$ & $\begin{array}{c}100, \\
0\end{array}$ & 200,0 & 100,0 \\
\hline
\end{tabular}

Keterangan: $\mathrm{BT}=$ Batang Tuaka, $\mathrm{K}=$ Keritang, $\mathrm{R}=$ Reteh, $\mathrm{TH}=$ Tembilahan Hulu, KM= Kerapatan Mutlak, FM= Frekuensi Mutlak, KN= Kerapatan Nisbi, FN= Frekuensi Nisbi, INP= Indeks Nilai Penting, NJD= Nilai Jumlah Dominansi. 


\section{UCAPAN TERIMA KASIH}

Penulis mengucapkan terima kasih kepada Kementerian Teknologi Riset dan Pendidikan Tinggi Indonesia dan LPDP yang telah memberikan beasiswa dan dukungan keuangan untuk penelitian ini. Kami juga berterima kasih kepada mahasiswa Fakultas Pertanian, Universitas Islam Indragiri atas dukungan dalam penelitian.

\section{DAFTAR PUSTAKA}

Desvayanti, G. (2002). Struktur dan Omposisi Gulma Pada Padi Sawah dengan Sistem Tanam Benih Sebar Langsung (Tabela) di Desa Pauh Kecamatan Pariaman Tengah Kabupaten Padang Pariaman. Skripsi Sarjana Biologi FMIPA Universitas Andalas. Padang.

Faisal, R., Siregar, E. B. M., \& Anna, N. (2011). Inventarisasi Gulma pada Tegakan Tanaman Muda Eucalyptus spp (Weed Inventory on Stand of Young Eucalyptus spp.). Peronema Forestry Science Journal, 2(2), 44-49.

Harsono, A. (2011). Implementasi Pengendalian Gulma Terpadu Pada Kedelai. Balai Penelitian Tanaman Kacangkacangan dan Umbi-umbian.

Kastanja, A. Y. (2011). Identifikasi jenis dan dominansi gulma pada pertanaman padi gogo (Studi kasus di Kecamatan Tobelo Barat, Kabupaten Halmahera Utara). Jurnal Agroforestri, 6(1), 40-46.

Kilkoda, A. K., Nurmala, T., \& Widayat, D. (2015). Pengaruh keberadaan gulma (Ageratum conyzoides dan Boreria alata) terhadap pertumbuhan dan hasil tiga ukuran varietas kedelai (Glycine max L. Merr) pada percobaan pot bertingkat. Kultivasi, 14(2).

Palijama, W., Riry, J., \& Wattimena, A. Y. (2018). Komunitas gulma pada pertanaman pala (Myristica fragrans $\mathrm{H}$ ) belum menghasilkan dan menghasilkan di Desa Hutumuri Kota Ambon. Agrologia, 1(2).

Pane, H., \& Jatmiko, S. Y. (2009). Pengendalian gulma pada tanaman padi. Jurnal Penelitian Pertanian Tanaman
Pangan. hlm, 267-293.

Purnomo, H. (2011). Perubahan Komunitas Gulma dalam Suksesi Sekunder pada Area Persawahan dengan Genangan Air yang Berbeda. Jurusan Pendidikan Biologi IKIP PGRI Semarang. Bioma, 1(2).

Rosmanah, S., \& Alfayanti. (2017). Identifikasi Gulma pada Dua Agroekosistem yang Berbeda di Kabupaten Seluma Provinsi Bengkulu. Prosiding Seminar Nasional Agroinovasi Spesifik Lokasi Untuk Ketahanan Pangan Pada Era Masyarakat Ekonomi ASEAN. Balai Pengkajian Teknologi Pertanian (BPTP). Bengkulu.

Sari, H. F. M., \& Rahayu, S. B. (2013). Jenis-jenis gulma yang ditemukan di perkebunan karet (Hevea brasiliensis Roxb.) Desa Rimbo Datar Kabupaten 50 Kota Sumatera Barat. Biogenesis: Jurnal Ilmiah Biologi, 1(1), 28-32.

Sastroutomo, S. (1990). Ekologi Gulma. Jakarta: Gramedia.

Sembodo, D. R. (2010). Gulma dan pengelolaannya. Graha Ilmu. Yogyakarta.

Sukma, Y., Yakup. (2002). Gulma dan Teknik Pengendalianya. Raja Grafindo Persada. Jakarta.

Suryaningsih, M. Jono, A. \& Darmadi, A. K. (2001). Inventarisasi Gulma Pada Tanaman Jagung (Zea Mays) Di Sawah Kelurahan Padang Galak, Denpasar Timur, Kodya Denpasar, Provinsi Bali. Simbiosisis. 1(1),1-8.

Tjitrosoedirdjo, S. (2010). Konsep Gulma dan Tumbuhan Invasif. J Gulma dan Tumbuhan Invasif Tropika, 1, 89-100.

Zulkarnain, Z. (2011). Pengaruh Ekstrak Patikan Kebo (Euphorbia hirta L) Terhadap Pertumbuhan Bakteri (Staphylococcus aureus dan Escherichia coli) dan Jamur (Candida albicans) (Doctoral dissertation, Universitas Islam Negeri Alauddin Makassar). 